\title{
Oxalate Determination in Urine Using an Immobilized Enzyme on Sorghum vulgare Seeds in a Flow Injection Conductimetric System
}

\author{
Graciliano de Oliveira Neto $^{a^{*}}$, Matthieu Tubino $^{a}$, Oswaldo Espirito Santo \\ Godinho $^{\text {a\# }}{ }^{\text {, Lauro Tatsuo Kubota }}{ }^{a}$, and João Roberto Fernandes ${ }^{b}$ \\ ${ }^{a}$ Instituto de Química da UNICAMP, C.P. 6154, 13083-970 Campinas - SP, Brazil; \\ e-mail:gon@iqm.unicamp.br \\ ${ }^{b}$ Faculdade de Ciências, Depto de Química, UNESP, Av. Luis Edmundo C. Coube s/n, \\ 17033-360 Bauru - SP, Brazil
}

Received: February 15, 1996; September 7, 1996

Desenvolveu-se um método por injeção em fluxo para determinação de oxalato em urina, baseado na utilização da oxalato oxidase (E.C. 1.2.3.4) imobilizada em sementes trituradas de Sorghum vulgare, variedade BR-303. Amostras de $200 \mu \mathrm{L}$ contendo oxalato são introduzidas num fluxo de água deionizada que passa por um reator, em forma de coluna, preenchido com o material enzimático ativado. O dióxido de carbono produzido pela reação enzimática é conduzido, pelo fluxo, até uma cela de permeação, contendo uma membrana de PTFE, onde permeia para um outro fluxo de água deionizada. Este fluxo passa por uma cela de condutividade. A presença de dióxido de carbono provoca uma diferença na condutividade, proporcional à concentração de oxalato originalmente presente na amostra. Os resultados obtidos mostram uma faixa de linearidade entre 0,05 e $0,50 \mathrm{mmol} \mathrm{dm}^{-3}$. O método proposto, quando comparado com o procedimento enzimático da Sigma, mostra uma boa correlação ( $\mathrm{Y}=$ $0,006( \pm 0,016)+0,98( \pm 0,019) \mathrm{X}, \mathrm{r}=0,9995, \mathrm{Y}=$ condutividade em $\mu \mathrm{S}$ e $\mathrm{X}=$ concentração em mmol $\mathrm{dm}^{-3}$ ), seletividade e sensibilidade. $\mathrm{O}$ novo procedimento de imobilização promove grande aumento de estabilidade da enzima permitindo a determinação de oxalato por cerca de seis meses. Cerca de 13 determinações podem ser realizadas por hora. A precisão do método proposto é bastante satisfatória (d.p.r. $= \pm 3,2 \%$ ).

A flow-injection (FI) method was developed for the determination of oxalate in urine. It was based on the use of oxalate oxidase (E.C. 1.2.3.4) immobilized on ground seeds of the BR-303 Sorghum vulgare variety. A reactor was filled with this activated material, and the samples $(200 \mu \mathrm{L})$ containing oxalate were passed through it, carried by a deionized water flow. The carbon dioxide produced by the enzyme reaction permeated through a microporous PTFE membrane, and was received in a water acceptor stream, promoting conductivity changes proportional to the oxalate concentration in the sample. The results obtained showed a useful linear range from 0.05 to $0.50 \mathrm{mmol} \mathrm{dm}^{-3}$. The proposed method, when compared with the Sigma enzymatic procedure, showed good correlation $(\mathrm{Y}=0.006( \pm 0.016)+0.98( \pm 0.019) \mathrm{X} ; \mathrm{r}=0.9995$, $\mathrm{Y}=$ conductivity in $\mu \mathrm{S}$, and $\mathrm{X}=$ concentration in $\mathrm{mmol} \mathrm{dm}^{-3}$ ), selectivity, and sensitivity. The new immobilization approach promotes greater stability, allowing oxalate determination for 6 months. About 13 determinations can be performed per hour. The precision of the proposed method is about $\pm 3.2 \%$ (r.s.d).

Keywords: flow injection, oxalate oxidase, oxalate determination, enzyme immobilization, Sorghum vulgare, conductimetry

\# Present address: Universidade Federal do Maranhão - São Luís 


\section{Introduction}

In recent years a large number of methods ${ }^{1-7}$ have been developed to immobilize enzymes on solid matrices. The most predominant method is that of carrier binding, and many commercially available immobilized enzymes are found with synthetic matrices. Crude materials like Sorghum vulgare may contain many organic compounds, mainly polysaccharides, proteins, and lipids. In this work we have used natural seeds activated with glutaraldehyde. The ionic interaction, hydroxyl groups from the polysaccharides, and proteins may be attracted by hydrophilic regions of the enzyme molecule, while lipid groups may supply additional attraction to the hydrophobic regions of the enzyme. In addition, the amino groups of the proteins may link with glutaraldehyde molecules and yield a cross linking interaction with the enzyme. With this kind of immobilization, the fragile enzyme molecules may be protected by an appropriate micro environment, different from those observed when artificial supports are employed. Nature was the first to realize this, since living organisms have many enzymes in the immobilized form.

The determination of oxalate in urine has been very important for the clinical diagnosis of various forms of hyperoxaluria and urinary tract stones ${ }^{8,9}$. Current methods for oxalate determinations include solvent extraction and precipitation $^{9}$, as well as colorimetric ${ }^{10}$, fluorimetric ${ }^{11}$, and chromatographic methods ${ }^{12-14}$. All of these methods require laborious sample pretreatment due to problems of interference. In addition, the majority of chromatographic methods involve HPLC, which presents high costs. On the other hand, an immobilized enzyme procedure has many advantages, such as selectivity and sensitivity, low cost and speed ${ }^{15}$. Generally, the purified enzymes are immobilized on inorganic matrices or polysaccharides. In all of them, matrix activation, sample preparation, and FI manifold demand complicated steps, including analyte separa$\operatorname{tion}^{1,2,16-21}$. For oxalate analysis, the most used enzyme has been the oxalate oxidase (E.C. 1.2.3.4) from different vegetables sources such as barley ${ }^{3}$, bananas ${ }^{4}$, amarantus ${ }^{5}$, sorghum $^{6}$, beets ${ }^{7}$, etc.

As far as we know, there are no methods that use the biological supports for enzyme immobilization that are or not employed in flow injection analysis described in the literature. As Sorghum vulgare seeds present naturally immobilized oxalate oxidase ${ }^{6}$, the pure enzyme can be easily immobilized onto its surface, increasing the enzyme activity, allowing the use of this material in the proposed FI method for oxalate determination. The use of such material presents advantages such as high stability and low cost.

This work describes a flow injection (FI) system for the determination of oxalate in urine, using a new support for enzyme immobilization and a flow conductimetric detector. The use of this natural support increases the stability and activity of the enzyme reactor. The carbon dioxide produced was detected using a conductimetric methodology.

\section{Experimental}

\section{Materials}

All reactants used were of analytical grade. Oxalate urine control, $N$, and $E$, oxalate oxidase (E.C.1.2.3.4), were obtained from Sigma (St. Louis). Standard oxalic acid solutions, with concentrations from 0.05 to $1.0 \mathrm{mmol} \mathrm{dm}^{-3}$, were prepared in a $0.05 \mathrm{~mol} \mathrm{\textrm {dm } ^ { - 3 }}$ sodium dihydrogenophosphate/phosphoric acid solution $(\mathrm{pH}=$ 3.0). Calibration curves were made daily with these solutions. A $10 \mathrm{mmol} \mathrm{dm}^{-3}$ oxalic acid solution was prepared, and suitable volumes were added to pre-treated urine specimens by the standard addition method. All measurements were performed using deionized water obtained from a NANOPURE $^{\circledR}$ deionizer $(0.056 \mu \mathrm{S})$. All data were expressed in millimol (mmol) of oxalic acid in $24 \mathrm{~h}$ urine specimens.

\section{Apparatus}

Peristaltic pump - Ismatec mp13 GJ4.

Conductivity meter - Micronal model B-331 connected to a chart recorder, Cole-Palmer 9375 series

Spectrophotometer - Single beam Micronal model B-382.

Conductimetric flow cell - as previously described ${ }^{22}$. $\mathrm{CO}_{2}$ Permeation cell - already published ${ }^{23}$.

\section{Sample preparation}

Several $24 \mathrm{~h}$ urine specimens were collected, and then appropriate dilutions were made in $0.05 \mathrm{~mol} \mathrm{dm}^{-3}$ sodium dihydrogenophosphate $\mathrm{pH} 3.0$ solution adjusted with phosphoric acid. Urine specimens were frozen when not in use.

The results were compared with those obtained by the enzymatic spectrophotometric method (Sigma Catalog no. 591C/94).

\section{Enzyme immobilization}

Sorghum vulgare seeds (BR-303) from EMBRAPA/BRAZIL were ground with a mortar and pestle and passed through a sieve to get homogeneous particles of about $1 \mathrm{~mm}$ in size. A $5 \mathrm{~g}$ amount was immersed in aqueous $25 \%(\mathrm{w} / \mathrm{v})$ glutaraldehyde solution overnight at $5{ }^{\circ} \mathrm{C}$. The supernatant was rejected and the pieces were washed ten times with deionized water and four times with 0.10 mol dm${ }^{-3}$ glycine solution. Further washing with deionized water was performed to eliminate the excess glycine. Two batches of $1.2 \mathrm{~g}$ of activated Sorghum vulgare seeds were submitted to immobilize the oxalate oxidase (Sigma O-4127); one with $0.42 \mu \mathrm{katal}$ and the other with 0.17 $\mu$ katal of the enzyme, and then $2 \mathrm{~mL}$ of a $0.05 \mathrm{~mol} \mathrm{dm}^{-3}$ 
succinate buffer ( $\mathrm{pH}$ 3.8) were added. Then, the mixtures were stored for a week in a refrigerator at $5{ }^{\circ} \mathrm{C}$. Finally these materials, after being washed with a $0.05 \mathrm{~mol} \mathrm{dm}^{-3}$ succinate buffer solution ( $\mathrm{pH} 3.8$ ), were used for the construction of the enzyme reactors.

\section{Method}

The enzyme reactor (a $100 \mathrm{~mm}$ length $/ 2.5 \mathrm{~mm}$ i.d. polyethylene tube) filled with the natural material, onto which oxalate oxidase was immobilized, was used in a typical FI set-up (Fig. 1). A conductimetric flow cell, with an internal volume of $25 \mu \mathrm{L}$ and a constant of $0.186 \mathrm{~S}$, was used in all measurements.

When injected (200 $\mu \mathrm{L}$ sample) into the carrier stream which passes through the enzyme reactor, the oxalic acid reacts with the enzyme to produce carbon dioxide. This $\mathrm{CO}_{2}$ permeates through the stretched polytetrafluoroethylene (PTFE) membrane into the second water stream changing the conductivity $\left(\mathrm{CO}_{2}+\mathrm{H}_{2} \mathrm{O}=\right.$ $\mathrm{HCO}_{3}{ }^{-}+\mathrm{H}^{+}$). In order to obtain a damping system for the flow, the waste tips were immersed at the same depth in a beaker completely filled with water. For comparison, a non-enzymatic reactor was employed, using a tube with the same dimensions, but having pieces of Styrofoam ${ }^{\circledR}$ as an inert filler material with a size similar to that of the Sorghum vulgare.

\section{Results and Discussion}

The immobilized sorghum seeds enzyme gave a reaction that showed reasonable stability for six months, i.e. carrying out about 20 assays per day, it remained at $65 \%$ relative activity. Apparently, the glutaraldehyde used in the immobilization process helps prevent the decomposition of the biological material by microorganisms.

The reactor with $0.42 \mu$ katal of enzyme gave a good performance and was used in all experiments. Assays were carried out using standard solutions to determine the best FI



Figure 1. The conductimetric FI manifold : A and B, deionized water carrier streams; P, peristaltic pump; S, sample inlet loop; ER, enzyme reactor; NR, non-enzymatic reactor; RI, ion exchange resin clean-up column; V, selection valve; SV, sampling valve system; PM, permeation cell; FC, conductance flow cell; $\mathrm{C}$, conductivity meter; R, chart recorder; and $\mathrm{W}$, waste. conditions. In Fig. 2, the influence of $\mathrm{pH}$ on the peak height is shown. The best enzyme activity occurs at $\mathrm{pH} 3.0$. Below this value, the enzyme lost activity, although at higher hydrogenionic concentrations the carbon dioxide permeation through the PTFE membrane is favored. At $\mathrm{pH}$ values above 3.0, the equilibrium is displaced to the right, decreasing the amount of $\mathrm{CO}_{2}$ that permeates through the PTFE membrane. As a consequence, a lowering of the signal was observed.

$$
\mathrm{CO}_{2}+\mathrm{H}_{2} \mathrm{O} \rightleftharpoons \mathrm{HCO}_{3}^{-}+\mathrm{H}^{+}
$$

Table 1 shows that the flow rate of $1.1 \mathrm{~mL} \mathrm{~min}^{-1}$ and 3.5 min for washing time were the best conditions established experimentally, when a polyethylene loop with a volume of $200 \mu \mathrm{L},(0.7 \mathrm{~mm}$ i.d.) was used. Despite the fact that with a flow rate of $0.67 \mathrm{~mL} \mathrm{~min}^{-1}$ higher signals are obtained than with $1.11 \mathrm{~mL} \mathrm{~min}^{-1}$, the washing time is increased 3.4 times, decreasing the sampling rate to a maximum of 4 per hour.

Table 1. The relationship between flow rate, peak height, and washing time for the FI method.

\begin{tabular}{|c|c|c|}
\hline $\begin{array}{l}\text { Flow Rate } \\
\left(\mathrm{mL} \min ^{-1}\right)\end{array}$ & $\begin{array}{l}\text { Peak Height } \\
(\mathrm{mm})\end{array}$ & $\begin{array}{l}\text { Washing Time } \\
(\mathrm{min})\end{array}$ \\
\hline 0.67 & 192 & 12.0 \\
\hline 0.86 & 175 & 6.0 \\
\hline 1.11 & 173 & 3.5 \\
\hline 1.34 & 160 & 3.0 \\
\hline
\end{tabular}

FI conditions: oxalic acid $0.50 \mathrm{mmol} \mathrm{dm}^{-3}, \mathrm{pH}=3.0, \mathrm{~T}=25.0 \pm 0.5^{\circ} \mathrm{C}$, and $200 \mu \mathrm{L}$ loop sample.

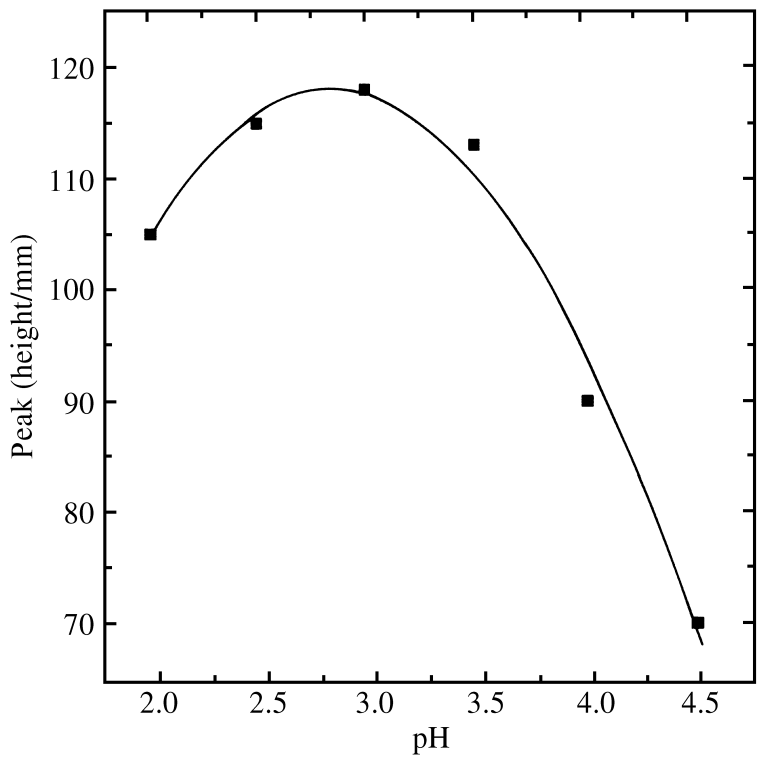

Figure 2. The effect of $\mathrm{pH}$ on the enzyme reactor for $0.50 \mathrm{mmol} \mathrm{dm}^{-3}$ oxalate standard solution in $\mathrm{NaH}_{2} \mathrm{PO}_{4} / \mathrm{H}_{3} \mathrm{PO}_{4}$ media. Temperature controlled at $25.0 \pm 0.5^{\circ} \mathrm{C}$. 


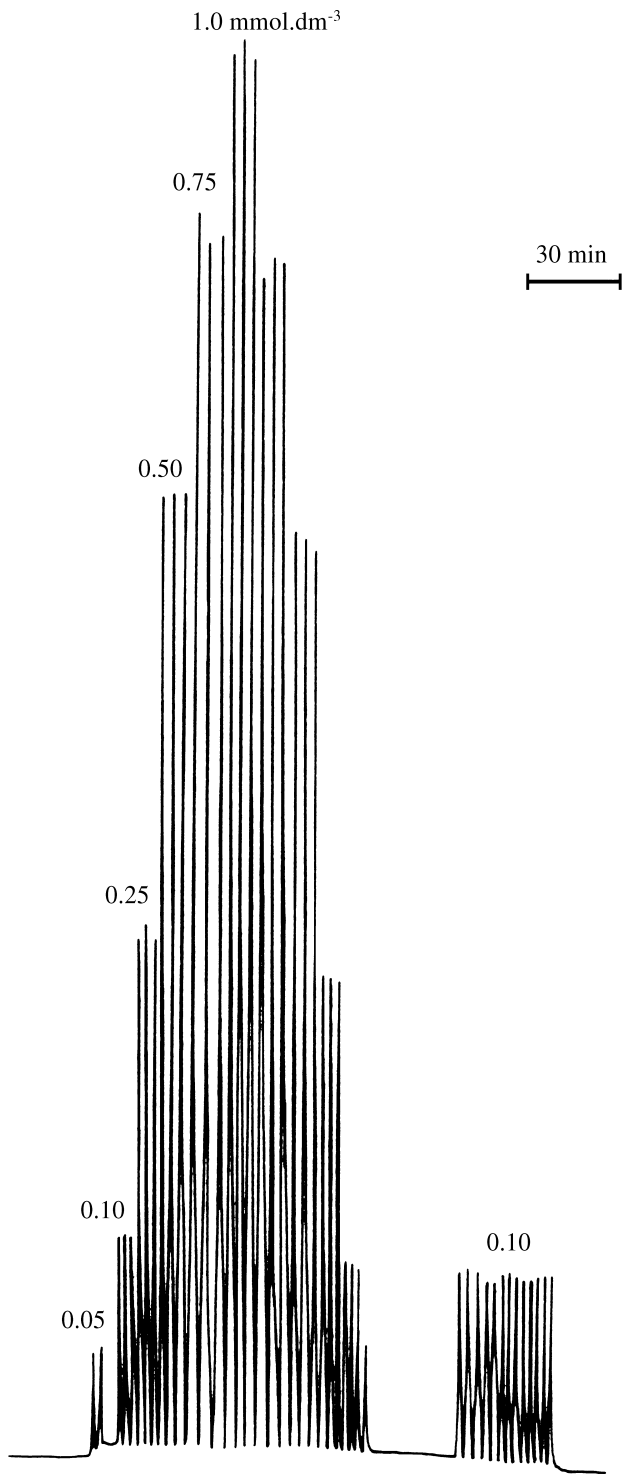

Figure 3. FI calibration runs for the determination of oxalic acid. From left to right: triplicate signals for oxalic acid standard solutions $(0.05$, $0.10,0.25,0.50,0.75,1.0 \mathrm{mmol} \mathrm{dm}^{-3}$, and the inverse order), with several additional signals from the $0.10 \mathrm{mmol} \mathrm{dm}^{-3}$ solution for a repeatability
A typical conductimetric FI profile and the repeatability for $0.10 \mathrm{mmol} \mathrm{dm}^{-3}$ are shown in Fig. 3. The calibration curve for oxalate determinations, obtained under the conditions described, presents a useful range between 0.05 and $0.50 \mathrm{mmol} \mathrm{dm}^{-3}$ of oxalic acid. This range can be fitted by a linear function $[Y=1.1( \pm 0.77)+229( \pm 3) X, r=0.9997$ for $\mathrm{n}=5$ ], with a relative standard deviation (r.s.d.) of $\pm 3.2 \%$.

Since urine matrices usually change significantly, the standard addition method was used for all determinations, making dilutions of the samples to the working range. The oxalate concentrations present in the sample can be obtained graphically by interpolation.

Urine specimens from 3 adult male donors, and $E$ and $N$ controls from Sigma were analyzed, using the established Sigma spectrophotometric method and the method proposed in this study. The results are shown in Table 2. The statistical $t$-test was used to compare the results obtained by the two methods. It can be observed that there are no significant differences between the results at a $95 \%$ confidence level.

The proposed FI method is simpler and less expensive. In addition, the sample pretreatment is eliminated, as is the interference from ascorbic acid. These features are not commonly found in other procedures ${ }^{2,4-7}$. The new immobilization approach appears to be very convenient since it preserves the enzyme activity at useful levels for a longer period of time.

The developed flow injection system for oxalate determination presented a useful concentration range from 0.05 mmol dm ${ }^{-3}$ up to $0.50 \mathrm{mmol} \mathrm{dm}^{-3}$. Although the main spectrophotometric and amperometric methods published show lower detection limits, they present several interference problems for biological sample analysis. The proposed method shows good performance for the determination of oxalic acid in urine without interference, presenting good operational advantages.

Table 2. A comparison between the values obtained by the Sigma spectrophotometric and the proposed FI methods for oxalate in urine specimens using the statistical student's $t$-test ${ }^{24}$.

\begin{tabular}{lccc}
\hline & \multicolumn{3}{c}{ Methods } \\
\hline Urines & $\begin{array}{c}\text { Spectrophotometric } \\
(\mathrm{mmol} / 24 \mathrm{~h})\end{array}$ & $\begin{array}{c}\text { Proposed } \\
(\mathrm{mmol} / 24 \mathrm{~h})\end{array}$ & $\begin{array}{c}\text { Calculated* } \\
t \text {-values }\end{array}$ \\
$\mathrm{N}^{*}$ & $0.29 \pm 0.01$ & $0.30 \pm 0.01$ & 1.00 \\
$\mathrm{E}^{*}$ & $1.31 \pm 0.02$ & $1.30 \pm 0.04$ & 0.30 \\
1 & $0.30 \pm 0.01$ & $0.28 \pm 0.01$ & 2.00 \\
2 & $0.16 \pm 0.01$ & $0.18 \pm 0.01$ & 2.00 \\
3 & $1.34 \pm 0.02$ & $1.31 \pm 0.04$ & 0.91 \\
\hline
\end{tabular}

Values presented in mmol/24 h. * Lyophilized urines reconstituted in 25 and $20 \mathrm{~mL}$ for $\mathrm{N}$ and $\mathrm{E}$ controls respectively. Daily final volume of these samples is $1.48 \mathrm{dm}^{-3}$. Tabulated $t$ value for the degree of freedom $(v) 4$ is $2.776(\alpha=0.05) ; v=n_{1}=n_{2}=3$ in this instance. 


\section{Acknowledgments}

The authors are indebted to Dr. José Avelino from the Centro Nacional de Pesquisa de Sorgo e Milho da EMBRAPA (Sete Lagoas-MG, Brazil) for supplying Sorghum vulgare seeds, BR-303 variety, and to FAPESP, CNPq, and CAPES/PICD for financial support.

\section{References}

1. Almuaibed, A.M.; Townshend, A. Anal. Chim. Acta 1989, $218,1$.

2. Gaetani, E.; Laureri, C.F.; Vitto, M.; Borghi, L.; Elia, G.F.; Novarini, A. Clin. Chim. Acta 1986, 156, 71.

3. Nabi-Rani, M.A.; Guilbault, G.G.; Oliveira-Neto, G. Anal. Chem. 1986, 58, 523.

4. Fonong, T. Anal. Chim. Acta 1986, 186, 301.

5. Mongkolisirikieat, S.; Srisuwan, C. J. Sci. Soc. Thail. 1987, 13, 169.

6. Pundir, C.S.; Kurchhal, N.K. Phytochem. 1989, 28, 2909.

7. Glazier, S.A.; Rechnitz, G.A. Anal. Lett. 1989, 22, 2929.

8. Wingaarden, J.B.; Elder, T.D. In The Metabolic of Inherited Diseases; McGraw-Hill, New York,1960.

9. Hodgkinson; H. In Oxalic Acid in Biology and Medicine; Academic Press. London, 1977.

10. Salinas, F., Martinez-Vidal, J.L.; Gonzalez-Murcia, V. Analyst 1989, 114, 1685.
11. Zarembski, P.M.; Hodgkinson, A. Biochem. J. 1965, 96, 717.

12. Santos, L.M.; Baldwin, R.P. J. Chromatogr. 1987, 414, 161.

13. Millán, A.; Grases, J.M.; Grases, F. J. Chromatogr. 1990, 529, 402.

14. Brega, A.; Quadri, A.; Villa, P.; Prandini, P.; Wei, J.Q.; Lucarelli, C. J. Chromatogr. 1992, 15, 501.

15. Sharma, S.; Nath, R.; Thind, S.K. Scanning Microscopy 1993, 7, 431.

16. Varalakshmi, P.; Richardson, K.E. Biochem. Int. 1992, 26, 153.

17. Bais, R.; Potezni, N.; Edwards, J.B.; Rofe, A.M.; Conyers, R.A.J. Anal. Chem. 1980, 52, 508.

18. Potezni, N.; Bais, R.; O'Loughlin, P.D.; Edwards, J.B.; Rofe, A.M.; Conyers, R.A.J. Clin. Chem. 1983, 29, 16.

19. Matsubara, C.; Sakai, K.; Takamura, K. Bunseki Kagaku 1991, 40, 343.

20. Fogg, A.G.; Alonso, R.M.; Fernandez-Arciniega, M.A. Analyst 1986, 111, 249.

21. Hansen, E.H.; Winther, S.K.; Gundstrup, M. Anal. Lett. 1994, 27, 1239.

22. Tubino, M. J. Flow Injection Anal. 1994, 11, 94.

23. Pasquini, C.; Faria, L.C. Anal. Chim. Acta 1987, 193, 19.

24. Eckschlager, K. In Errors, Measurements and Results in Chemical Analysis; Van Nostrand Reinhold, New York, 1972.

FAPESP helped in meeting the publication costs of this article. 